Revista Iberoamericana, Vol. LXVIII, Núm. 199, Abril-Junio 2002, 417-440

\title{
"UN DINAMISMO ABRASADOR": LA VELOCIDAD DEL CINE MUDO EN LA LITERATURA IBEROAMERICANA DE LOS AÑOS VEINTE Y TREINTA
}

\author{
POR \\ J. Patrick Duffey \\ Austin College
}

Con las 7 velocidades del mundo
corre el auto por el paisaje...
en cada vuelta del dinamo pasan
las estaciones los viñedos el sol
cinematograficadízimamente....
Juan Marín, “Klaxon”(1926), Looping

El chileno Juan Marín (1900-1963), además de poeta y ensayista, era también piloto, médico y muy aficionado a todos los ritmos modernos de los años veinte y treinta, los ritmos de los últimos bailes, de los deportes nuevos y del cine, como se ve en los títulos de los poemas de su libro Looping: “Fox Trot”, “Shimmy”, “Josephine Baker”, “Spin”, "Boxing”, “Oceanic Film”. ${ }^{1}$ El poema del epígrafe, "Klaxon”, establece una conexión entre dos de estos ritmos modernos, el del cine y el de los coches. Marín compara las imágenes que pasan por las ventanillas del coche ("las estaciones los viñedos el sol”) con las imágenes que pasan rápidamente por las pantallas del cine, utilizando el neologismo “cinematograficadízimamente”, una combinación ridícula de las palabras “cinematográfico” y "rapidísimamente”. Muchos escritores iberoamericanos hicieron conexiones parecidas en sus obras literarias durante este período. La velocidad del cine mudo convirtió la velocidad cotidiana en algo nuevo, en un ritmo más acelerado, más ligero. El cine proporcionó un modo nuevo de percibir la velocidad del mundo moderno, por ejemplo, la velocidad de las imágenes que pasaban por las ventanillas de los vehículos rápidos.

Este estudio tiene dos objetivos principales: 1) examinar la influencia de la velocidad del cine mudo en la literatura iberoamericana de los años veinte y treinta; y 2) analizar cómo las actitudes positivas y negativas de los escritores hacia la velocidad reflejan los cambios en el concepto del arte durante esta época. El presente ensayo difiere de enfoques anteriores, porque analiza el impacto del cine mudo en la literatura iberoamericana en general. Existen estudios de la influencia del cine mudo en otras literaturas, pero son escasos los que se han dedicado a la literatura hispana. ${ }^{2}$ C. Brian Morris, Beatriz Sarlo y

${ }^{1}$ El estudio de James O. Swain provee más detalles de la vida fascinante del Dr. Marín.

${ }^{2}$ Véase The Age of the American Novel: The Film Aesthetic of Fiction Between the Wars, de ClaudeEdmonde Magny; Literature and Film, de Robert Richardson; The Cinematic Imagination: Writers and Motion Picture, de Edward Murray; Film and the Camera Eye: Visual Consciousness in Film 
Flora Süssekind han examinado el efecto del cine mudo en la literatura de España, de Argentina, y de Brasil, respectivamente. ${ }^{3}$ Hay numerosos estudios de la relación entre el cine y la narrativa de varios autores del llamado "Boom”-García Márquez, Fuentes, Cabrera Infante, y Puig. ${ }^{4}$ La tesis de este estudio es que la velocidad del cine mudo constituyó una experiencia única para los escritores iberoamericanos de los años veinte y treinta, ya que posteriormente el sonido habría de cambiar todo: la velocidad expresada por el cine sonoro tuvo que disminuir, porque había que reducir la velocidad para captar el sonido de la voz. Asimismo, es importante estudiar el impacto de la velocidad cinematográfica como un fenómeno internacional, porque así fue durante esta época. El silencio del cine mudo permitió una transcendiencia de las fronteras tanto nacionales como lingüísticas. Además, es importante notar que el cine mudo se producía no sólo en Hollywood y Europa. Durante las primeras décadas del siglo xx, el público iberoamericano acudía al cine para ver numerosas producciones autóctonas, especialmente en México, Argentina y Brasil. ${ }^{5}$

Muchos escritores iberoamericanos elogian en sus obras la velocidad del cine mudo. En "El día más feliz de Charlot: Cuento cinematográfico en cuatro escenas y un apoteosis" (1928), Enrique González Rojo (uno de los Contemporáneos) crea una versión literaria de Chaplin que personifica lo bueno de la velocidad. Vicente Huidobro inventa una versión hollywoodense del Cid en su "novela-film” Mío Cid Campeador (1929), en la cual el héroe castellano es un atleta moderno con "una violenta necesidad de movimiento" (Obras II: 808-809). Huidobro capta los movimientos rápidos del Cid con las lentes cinematográficas de los ojos de sus personajes. En "El elemento ritmo en el cine y en el deporte" (1929), el crítico de arte Jorge Romero Brest, como otros escritores del período, percibe una conexión entre el "dinamismo abrasador" del cine, de los deportes, de la literatura contemporánea. Numerosos autores escriben escenas que expresan la velocidad de los vehículos rápidos en términos cinematográficos: los mexicanos Salvador Novo, Jaime Torres Bodet, Mariano Azuela, Martín Luis Guzmán; el peruano Xavier Abril; los brasileños João do Rio y Oswald de Andrade. Otros escritores, sin embargo, presentan la velocidad del cine en términos negativos. La variedad de las actitudes refleja la lucha

and the Modern Novel, de Alan Spiegel; Film and Fiction: The Dynamics of Exchange, de Keith Cohen; y una colección de ensayos reciente, editada por Leo Charney y Vanessa R. Schwartz, Cinema and the Invention of Modern Life.

${ }^{3}$ Véase a C. Brian Morris, This Loving Darkness: The Cinema and Spanish Writers, 1920-1936; a Beatriz Sarlo en Una modernidad periférica: Buenos Aires 1920 y 1930 y La imaginación técnica: Sueños modernos de la cultura argentina; y a Flora Süssekind, Cinematógrafo de letras: Literatura, técnica e modernização no Brasil. Para un análisis de las técnicas cinematográficas de la novela vanguardista mexicana, véase a J. Patrick Duffey, De la pantalla al texto: La influencia del cine en la narrativa mexicana del siglo $\mathrm{xx}$.

${ }^{4}$ Para unos ejemplos representativos, véase a Joseph Tyler, "The Cinematic World of García Márquez"; a Lanin A. Gyurko, "La muerte de Artemio Cruz and Citizen Kane: A Comparative Analysis"; y a Kenneth E. Hall, "Cabrera Infante and the Work of Alfred Hitchcock".

${ }^{5}$ Para un análisis de las películas documentales, nacionalistas y dramáticas de la primera época del cine en América Latina, véase el estudio minucioso y reciente de Ana M. López, "Early Cinema and Modernity in Latin America”. 
intelectual entre lo artificial y lo humano durante esta época. El cine representa una velocidad artificial que es muy atractiva y a veces inquietante para los escritores. Según Walter Benjamin, el cine, al reproducir la imagen original, le quita el “aura” a ésta, es decir, le quita la posibilidad de ser única. En mi opinión, el cine no sólo reproduce la imagen original, sino que la supera en ciertos aspectos. El cine acelera la realidad, le infunde una energía nueva, moderna, artificial. Lo artificial se convierte en algo atractivo o inquietante, y no sólo para los vanguardistas. Muchos escritores iberoamericanos-ya sean vanguardistas o no-imitan y manipulan la velocidad cinematográfica según sus propósitos literarios.

Pero ¿por qué esta velocidad cinematográfica es tan importante para estos escritores? ¿Cómo llegaron a ser tan sensibles a la velocidad moderna? ¿De dónde viene este concepto tan positivo de la velocidad? ¿Cómo servía la velocidad del cine mudo para ayudar a los escritores a ver el mundo de diferente forma? ¿Cómo ayudaba la velocidad cinematográfica a definir "lo moderno"? Examinemos brevemente la trayectoria del concepto de la velocidad en las primeras décadas del siglo xx y su relación con el cine mudo.

\section{EL CINE MUDO Y EL CONCEPTO DE LA VELOCIDAD MODERNA}

Durante la primera mitad del siglo xx, los trenes, los aviones, los automóviles, los deportes y el cine - y la velocidad que se asociaba con todos ellos- eran todavía fenómenos nuevos, abrumadores, liberadores para los escritores y artistas del mundo. El manifiesto futurista de F. T. Marinetti de 1909 proclamó la belleza de la velocidad, y durante los próximos veinte años los pintores futuristas como Balla, Russolo y Dottori intentaron capturar el dinamismo de los trenes, los aviones, los coches, las bicicletas, y hasta un perrito meneándo la cola. El jazz, los bailes de las “flapper,” el fútbol, el rugby, el baloncesto, los automóviles, los aviones y la manera acelerada de caminar de un vagabundo con su bastoncito - todos eran inventos de la primera parte del siglo xx, y todos parecían manifestar la belleza de la velocidad marinettiana. Estas velocidades nuevas a veces convergen y se influyen mutuamente. En los años veinte, algunos escritores empezaron a comparar las imágenes rápidas que pasaban a través de las ventanas de los trenes, los aviones y los automóviles a las imágenes que volaban por las pantallas cinematográficas. Otros escritores encuentran una conexión entre la experiencia del acto de mirar los rápidos movimientos de futbolistas o de boxeadores y las experiencias del acto de mirar las imágenes rápidas de la pantalla de plata. La velocidad del "ragtime” y del “jazz” encuentra un fenómeno análogo en el ritmo acelerado del cine.

La velocidad era una fuerza unificadora durante las primeras décadas del siglo xx. El cineasta Jean Epstein leyó el manifiesto marinettiano de 1916 con el título "La nueva religión moral de la velocidad.” En 1921, Epstein escribió un ensayo muy difundido que apareció en inglés al año siguiente como "The New Conditions of Literary Phenomena" en la prestigiosa revista vanguardista Broom. Epstein describe cómo la velocidad había cambiado la percepción visual de los escritores:

Ya no tenemos una noción sencilla, clara, continua y constante del objeto. El hombre ha visto un paisaje no sólo con sus propios ojos mientras caminaba, sino también desmoronado 
por la velocidad por las ventanillas de un tren, desde el asiento de un automóvil a pesar del viento y el polvo, desplegado como una reproducción de un museo geográfico por los gemelos, en una vitrina, en las fotos, sacadas de la izquierda, de la derecha, al sol, a la sombra, sin o con filtro, en el cine, pintado por un pintor, dibujado por un artista, cantado por un poeta. (6; traducción mía)

Guillermo de Torre, poeta español, editor, traductor e historiador por excelencia de la vanguardia española, promulgó muchas de las ideas de Epstein en su imprescindible historia Literaturas Europeas de Vanguardia de 1925. El ensayo de Epstein sugiere que había una abundancia de influencias mutuas en esta época. La velocidad de los vehículos cambió la visión paisajística de los escritores. El cine, ya una fuente de por sí de imágenes rápidas, representó las imágenes del paisaje que volaban por las ventanillas de los vehículos, e intensificó esta experiencia. Los escritores, influídos por el transporte rápido, el cine, y otros aspectos de la vida moderna, empezaron a incorporar escenas de la velocidad de los vehículos y del cine en sus obras narrativas y poéticas. El novelista y ensayista Antonio Espina en un artículo para El Sol describió mejor que nadie la conexión entre la velocidad cinematográfica y las demás velocidades. Según Espina, no hubiéramos percibido las velocidades modernas si no hubiera habido un cine que las expresara de una manera tan potente:

Posiblemente, casi seguro, el peculiar estilo rítmico de la vida moderna se nos hubiese escapado si no existiese la pantalla cinematográfica. En ésta es donde hemos descubierto el gran sentido desfilatorio que anima la modernidad. La "vida visual”, antes tan quieta, ha tomado cuerpo y desfila vertiginosamente en los millares de pantallas del mundo. Como desfilan los árboles de la carretera a los flancos del "auto” veloz, y las letras de un anuncio eléctrico al encenderse y apagarse, y ciudades y paisajes extendidos en mapa bajo el vuelo del aeroplano. (12)

A Espina le parece obvio que hay una conexión entre la velocidad vertiginosa de las imágenes en una pantalla cinematográfica y su propia capacidad para apreciar las imágenes que vuelan por la ventana de un avión o de un coche. ¿Por qué le parece tan obvio? ¿Por qué el cine mudo le es imprescindible para apreciar "el peculiar estilo rítmico de la vida moderna..... [e]l gran sentido desfilatorio que anima la modernidad”?

El cine mudo cambió la visión de la realidad de los escritores. Les ofreció una manera de comprender lo fragmentario del mundo moderno y disfrutar de lo efímero de las nuevas velocidades. Según Leo Charney, el cine mudo era la forma de expresión artística que mejor representaba la experiencia moderna de lo temporal. ${ }^{6}$ Walter Pater, Martin Heidegger y Walter Benjamin postulan de varias maneras que la realidad moderna es una abundancia abrumadora de momentos fugaces y que resulta imposible disfrutar de estos momentos porque el ser humano no puede, simultáneamente, sentir el momento y ser intelectualmente consciente de esta sensación. ${ }^{7}$ La enajenación moderna resulta del hecho

\footnotetext{
${ }^{6}$ Charney presenta un análisis esmerado de la trayectoria ideológica del concepto del tiempo moderno y su relación con el cine mudo en su "In a Moment: Film and the Philosophy of Modernity". ${ }^{7}$ Véase a Walter Pater, Studies in the History of the Renaissance (1873); a Martin Heidegger, Being and Time (1927); para el texto de Benjamin, véase a Gary Smith, ed. Benjamin: Philosophy, Aesthetics, History.
} 
de que las personas experimentan la vida como una serie infinita de fragmentos rápidos e insignificantes. Charney señala que la velocidad del cine mudo ofrecía una forma de conectar estos fragmentos caóticos de la vida diaria. El público del cine mudo podía experimentar el placer de las imágenes rápidas de la pantalla cinematográfica y por unos breves momentos, en la oscuridad del cine, las personas podían disfrutar del placer de la rapidez moderna. Según Jean Epstein, este placer — la photogénie - es el epítome del placer moderno, deleitarse en la concatenación rápida de los fragmentos momentáneos de la experiencia visual. Charney concluye que el movimiento rápido de las imágenes de cine reflejaba perfectamente la experiencia epistemológica de la modernidad a principios del siglo xx (293).

Otro crítico de cine mudo, Tom Gunning, ha estudiado la estética de las películas mudas anteriores al cine narrativo, obras que forman lo que él llama el "cine de atracciones". ${ }^{8}$ Gunning sugiere que estas películas — como la de un tren que parecía acercarse al público rápidamente- tenían mucha aceptación porque al público de aquel entonces le encantaba el placer de lo asombroso: la imagen chocante de un elefante electrocutado; las imágenes panorámicas del paisaje filmadas desde un tren en movimiento; un beso íntimo entre un hombre y una mujer. Estas películas de atracciones de la primera década del siglo xx tenían un impacto significativo en las expectativas del público cinematográfico y su influencia seguía siendo importante en los años veinte y treinta. Como los espectadores del cine de atracciones, el público de las décadas posteriores apreciaba lo asombroso también. Gunning señala, por ejemplo, la descripción de Siegfried Kracauer en los años veinte sobre la recepción de las películas en Berlín: "Las estimulaciones de los sentidos se suceden con tanta rapidez que no queda espacio para el más mínimo pensamiento [traducción mía]” (“An Aesthetic” 127). Los espectadores buscan distraerse por medio de la rapidez de las imágenes.

En otro estudio, Gunning afirma que el cine de atracciones inspiraba especialmente a los escritores vanguardistas. ${ }^{9}$ Por ejemplo, Fernand Léger y F.T. Marinetti reconocieron que la potencia única del cine era su capacidad de mostrar y exhibir la realidad de una forma más concentrada. Después de ver La Roue de Abel Gance en 1922, Léger notó que el poder especial del cine era "una cuestión de hacer visibles las imágenes”. ${ }^{10}$ Marinetti declaró en 1913 que el cine de atracciones había creado un espectador más activo al crear un espectador más estimulado visualmente. ${ }^{11}$ Según Gunning, a los vanguardistas les fascinaba el cine de atracciones precisamente por su cualidad exhibicionista. El cine de atracciones no narraba tanto como estimulaba. Muchos escritores de los años veinte y

\footnotetext{
${ }^{8}$ Los tres estudios más relevantes de Gunning son "The Cinema of Attractions: Early Film, Its Spectator and the Avant-Garde" (1986); "An Aesthetic of Astonishment: Early Film and the (In)Credulous Spectator” (1989); y “'Now You See It, Now You Don’t': The Temporality of the Cinema of Attractions" (1993).

${ }^{9}$ En "The Cinema of Attractions: Early Film, Its Spectator and the Avant-Garde”, Gunning señala que la primera generación de vanguardistas - los futuristas, los dadaístas y los surrealistas — solían coincidir en su fascinación con las posibilidades del cine.

${ }^{10}$ Traducción mía. Citado por Gunning, "The Cinema of Attractions" 56.

${ }^{11}$ Citado por Gunning 59. En F.T. Marinetti, “The Variety Theater 1913” en Umbro Apollonio, ed. Futurist Manifestoes.
} 
treinta, como los espectadores de estas películas, veían en la velocidad del cine mudo algo asombroso que les fascinaba, que les estimulaba. Según Benjamin y Kracauer, las personas modernas buscan lo asombroso porque ya no pueden sentir otra cosa, están embotadas. Gunning añade que la realidad moderna está llena de tantos estímulos que sólo lo sorprendente, lo desconcertante, lo chocante — lo cinematográfico—-puede impresionar o estimular (“An Aesthetic” 128).

Para los escritores de esta época, los actores del cine mudo habitaban un mundo asombroso, atractivo, una pantalla mágica donde todos pisaban con pasos ligeros sin esfuerzo alguno. En las películas mudas, las personas parecen moverse a un ritmo mucho más acelerado de lo normal. La aceleración hacía posible muchos momentos tanto cómicos como acrobáticos. Chaplin y Keaton, por ejemplo, crearon escenas con la precisión coreográfica de un ballet y la rapidez de una máquina. Muchos autores iberoamericanos compartían los sentimientos del ensayista español Fernando Vela cuando éste afirmó en 1928 en Revista de Occidente que Chaplin era "de una raza más menuda, más rápida, más ágil que vive en el cine” (235). Así que, para los escritores de esta época, el cine era la quintaesencia en la expresión de la velocidad. Al llegar el cine sonoro (empezando con el Jazz Singer de 1927), el cine disminuyó su característica rapidez. La velocidad cinematográfica ya no era una fuerza que penetraba la cultura tanto como antes. Pero para los autores de los años veinte (y para algunos de los treinta), el impacto de este ritmo frenético fue considerable. Para varios de ellos, Chaplin era el que mejor encarnaba la velocidad del cine mudo.

CHARLOT Y “LA GENIALIDAD DEL PRONTO”

No se puede exagerar la popularidad mundial de Charlie Chaplin — “Charlot”durante los años veinte y treinta. En España, por ejemplo, muchos escritores durante estos años produjeron ensayos u obras literarias sobre Charlot: Ramón Gómez de la Serna, César M. Arconada, Antonio Espina, Francisco Ayala, Benjamín Jarnés y Rafael Alberti. Intentaron explicar un poco el fenómeno chapliniano, encontrar el origen del encanto especial de su humor. Ellos y los críticos posteriores han señalado, por ejemplo, que el humor de Chaplin desafía las convenciones burguesas; que su humor es un emblema de la libertad individual; que representa perfectamente el espíritu lúdico e infantil del que hablaba Ortega y Gasset en La deshumanización del arte de 1925.12 No cabe duda de que estas ideas nos dicen mucho del humor de Chaplin, pero hay otra explicación del humor de Charlot que no ha recibido mucha atención crítica, la cual lo atribuye en parte a su velocidad vertiginosa. Dos escritores de la vanguardia española hacen hincapié en la velocidad cómica de las películas de Chaplin, Fernando Vela y César M. Arconada. En un ensayo de 1928 para la Revista de Occidente, Fernando Vela descubre el poder cómico de Charlot en "su pasito menudo y rápido y su va-y-vuelve incesante” (232). Para Vela, Charlot es un acróbata sobre la cuerda floja, un hombre con "menudo cuerpo" que tiene "efectos, recursos, resortes que, en cuanto son oprimidos un poco, se disparan como

\footnotetext{
${ }^{12}$ Véase a José M. del Pino, “El héroe est-ético de la vida moderna: Charlot y los vanguardistas
} españoles”. 
gatillos”. Según Vela, el humor de Charlot reside en su capacidad de llenar cada segundo con una velocidad sorprendente y cómica:

Charlot ha quitado la silla al director del circo; el director se sienta; pero, en la última milésima de segundo, el brazo de Charlot, con una precisión mecánica de biela, pone la silla. Charlot reivindica el instante, la genialidad del pronto, la inventiva que sólo trabaja en el apuro y la urgencia. (234)

Vela hasta sugiere que "la genialidad del pronto” de Charlot no sólo es cómica, sino que también es un desafío a lo convencional: "Charlot es el mejor remedio contra la inercia de la masa que rebulle en el cine oscuro. Esta agilidad de Charlot para vencer la pereza de la materia y del espíritu con sólo un bastón de junco acelera la pulsación del vulgo lento" (234). La velocidad cinematográfica de Charlot es un elíxir humorístico que alivia algo de la enfermedad que el mentor de Vela, el mismo Ortega y Gasset, examinaría en su Rebelión de las masas: "Cuando la multitud sale de una película de Charlot, se ve que trota mejor” (234). La tecnología del cine le permite a Charlot atrapar el instante.

En 1930, César Arconada, novelista y crítico español, publicó en Buenos Aires un ensayo sobre Charlot (que después apareció en España en 1931 en su libro 3 cómicos del cine) en el cual vincula muy explícitamente el humor de Chaplin a su velocidad cinematográfica:

[Chaplin] tiene contra el automatismo un procedimiento de desarrollo rápido, acelerado, lleno de urgencia de realizaciones. Su dinamismo es incansable, como hombre que tiene necesidad de desarrollar un largo programa de efectos en un corto plazo. Gran parte de su comicidad la produce por esta aceleración. (26)

Arconada señala que con mucha frecuencia Chaplin yuxtapone un tiempo acelerado con otro lento para crear una estructura que permita un descanso entre las risas. Otros ensayos sobre Charlot aparecieron en las revistas iberoamericanas al final de los años veinte. El poeta peruano Xavier Abril publicó un ensayo con el título "Radiografía de Chaplin” en 1928, y el escritor norteamericano Waldo Frank escribió (en castellano) un "Retrato de Chaplin" que salió en la revista Contemporáneos en julio de 1929, justo cuando Frank empezó su gira por América Latina, dando cuarenta y dos conferencias en México, Argentina, Bolivia, Perú, y Cuba (publicadas en 1930 en su libro Primer mensaje a la América Hispana).

Es notable que Contemporáneos publicara este ensayo de Frank, porque no era crítico de cine. Frank se había concentrado más en otros temas (por ejemplo, la cultura norteamericana, la española), y sólo había escrito un ensayo sobre Chaplin antes (escrito en inglés en 1924). ${ }^{13}$ Creo que indica que a los Contemporáneos, y a muchos escritores del período, les fascinaba el cine en general, Chaplin en particular, y la velocidad alegre del cine mudo que expresaban las películas de Chaplin, especialmente las que salieron

\footnotetext{
${ }^{13}$ Frank había analizado la cultura norteamericana en Our America (1919) y la española en Virgin Spain: Scenes from the Spiritual Drama of a Great People (1926). Su primer ensayo sobre Chaplin apareció en Salvos (1924).
} 
antes de Luces de la ciudad (1931). El ensayo de Frank anticipa algunas de las ideas de su siguiente libro sobre la cultura latinoamericana, América Hispana (1931), en el cual sugiere que América Latina tiene una riqueza espiritual, mientras Norteamérica posee sobre todo una energía, un dinamismo, que proviene del conocimiento tecnológico. Como el chileno José Enrique Rodó en su ensayo Ariel (1900), Frank critica la idolatría materialista de Norteamérica y alaba los valores espirituales y estéticos de las tierras del sur. Frank incluso recomienda una síntesis de la energía tecnológica del norte y el espíritu estético del sur. Para Frank, Charlie Chaplin personificaba el dinamismo norteamericano (aunque el actor era inglés, sus películas eran productos “hollywoodenses”). La caracterísica esencial de Chaplin es su incesante velocidad: "La vida, pues, de este primer maestro del cine, es el movimiento” (296). En los cortometrajes, Quimera de oro (1924), El circo (1927), y otras obras antes de Luces de la ciudad, Chaplin, para Frank, representa el dinamismo individual que puede superar la lentitud triste de las masas modernas. Según Frank, una película de Charlot es "un movimiento de sucesos que representa el viaje del hombre: su fuga, intacto, a través de la masa innumerable de la vida” (298). "El ritmo inexorable” de estas películas le permite al actor británico una manera de enfrentarse a la pobreza y al caos de la vida moderna.

Nueve meses antes de la publicación del "Retrato de Chaplin” de Frank, y cinco meses después de la publicación del ensayo sobre Charlot de Fernando Vela en Revista de Occidente, Enrique González Rojo (1899-1939) publicó en Contemporáneos su cuento "El día más feliz de Charlot” con el subtítulo “Cuento cinematográfico en cuatro escenas y un apoteosis.” El cuento es una expresión literaria excelente de la idea de la velocidad cómica y optimista de Charlot y de la lentitud opresiva del mundo donde vive.

El protagonista, Charlot, viaja a Nueva York en un barco con otros inmigrantes. Mientras los otros caminan con "pasos lentos" y contemplan "estúpidamente el mar," Charlot es un pasajero de mucho optimismo y de mucho movimiento frenético. Cuando el malvado del cuento, un “gigante,” empuja a Charlot, éste se levanta rápidamente porque "se sirve de la fuerza elástica del índice que resbala sobre el pulgar” (115). Los otros pasajeros duermen y cruzan sus manos por detrás de la cabeza y “así permanecen inmóviles durante minutos, horas, días” (116). González Rojo yuxtapone esta inmovilidad con la velocidad alegre de Charlot, cuando describe cómo éste camina entre tantas personas inmóviles: "Mirad cómo resuelve el problema. Con mil precauciones se desliza, salta, sortea con habilidad los peligros" (116).

En la segunda escena, Charlot descubre a una muchacha de cabellos dorados, un ser de una velocidad parecida. Ella también tiene que caminar con mucha destreza entre los otros inmóviles pasajeros. Hay tantos obstáculos humanos que Charlot y la muchacha no pueden encontrarse. Charlot juega a las cartas con un frenesí típico de él, con "sus constantes movimientos," su “mano derecha que va y vuelve,” y su cabeza que "se inclina con inusitada rapidez” (121-2). En la tercera escena, el gigante pisa la mano de nuestro héroe, Charlot no puede ver la última carta, pero moviendo los muslos "con velocidad insospechada,” puede ver que la última carta es el as de espadas, el símbolo de la muerte. ¿Quién va a morir? En la cuarta escena de este cuento-film el gigante y Charlot luchan para determinar a quién le tocara esta suerte. Pero Charlot es demasiado rápido para el gigante y lo vence con una serie de maniobras aceleradas y cómicas: “[Charlot] avanza, retrocede, 
salta, se agacha, embiste, acciona con sus débiles brazos, se escabulle” (127-8). El gigante — confundido por tanta velocidad cómica — se cae al mar, y Charlot y su amada rubia viven veloces y felices para siempre.

Once años antes de la publicación de este cuento, Chaplin había escrito y dirigido un cortometraje famoso, El Inmigrante (1917), el cual comparte ciertos elementos con el cuento de González Rojo. Las diferencias son muchas también, y son tan interesantes como las semejanzas. Como en el cuento, la película empieza con la escena de los inmigrantes en el buque. En las dos obras, Charlie tiene más energía que los demás viajeros. Como en el cuento, los demás están tumbados en la cubierta del barco, sin moverse. En la película, la gente no se puede mover porque la nave da muchos bandazos. Varios pasajeros están vomitando en el mar. En una escena, se ve a Charlie desde atrás, en la postura de alguien que está vomitando en el mar. Después de un ratito, sin embargo, se nos revela que Charlie estaba agachado de esa manera no para vomitar sino para hacer algo más divertido y útil — para pescar. Como en los ensayos de Vela y de Frank, y como en el cuento de González Rojo, el Chaplin del cortometraje parece haber superado el letargo y la inercia de las masas. A diferencia de los demás pasajeros, Charlie puede caminar, a pesar del movimiento del barco. De hecho, parece que al protagonista le encanta la inestabilidad del buque, porque le permite una forma de andar más acrobática. La velocidad optimista de Charlot es su gran arma en su lucha contra el mundo que lo amenaza constantemente. En las dos obras, Chaplin se enamora de una mujer idealizada a bordo del barco, lucha con un gigante, gana porque es más rápido, y juega muy rápidamente a las cartas (en el cuento es la mano derecha de Chaplin que va y vuelve con tanta celeridad; en la película, es la mano izquierda). Tanto la película como el cuento expresan el poder de la velocidad del protagonista frente a la lentitud de las masas. Para González Rojo, como para otros escritores, Chaplin representaba más que nada una velocidad frenética y liberadora.

\section{LA VELOCIDAD CINEMATOGRÁFICA Y LOS VEHÍCULOS MODERNOS}

Durante los años veinte, los escritores de España, los de Iberoamérica, y los de otros muchos países del mundo, empezaron a hacer la conexión entre las imágenes veloces del cine mudo y las imágenes que pasaban por las ventanillas de los coches, los trenes, y los aviones. Antes de esta década, los autores a veces comentaban la rapidez de las imágenes vistas desde las ventanillas, pero no las relacionaban con el cine. Por ejemplo, en uno de los poemas de Campos de Castilla (1917), Antonio Machado describe lo que ve mientras viaja en tren:

Tras la turbia ventanilla,

pasa la devanadera

del campo de primavera....

Resonante,

jadeante,

marcha el tren. El campo vuela.

(CXXVII, “Otro viaje” 189) 
Aquí se ve la velocidad moderna, pero no es la velocidad cinematográfica. Al llegar los años veinte, sin embargo, empiezan a aparecer referencias literarias a la conexión entre la velocidad del cine mudo y la de los vehículos modernos. En el poema del epígrafe, cuando el coche de Juan Marín corre por el paisaje, las imágenes pasan por la ventanilla “cinematograficadízimamente”. Se puede dividir los pasajes de este tipo en dos categorías: 1) los que hacen una comparación explícita; y 2) los que no hacen una comparación explícita sino que sólo sugieren la velocidad visual del cine mudo. Hay abundantes ejemplos de la primera categoría en la literatura de Iberoamérica y de España. ${ }^{14}$

En 1909, el brasileño João do Rio, escritor de crônicas y novelas, hizo una conexión explícita entre la velocidad del cine mudo y la de los vehículos en su colección de crônicas titulada Cinematógrafo. Flora Süssekind, en su excelente estudio Cinematógrafo de letras: Literatura, técnica e modernização no Brasil (1987), señala que João do Rio asocia la crônica (los retratos medio periodísticos, medio literarios tan importantes en la literatura brasileña) con el cine. Las crônicas, como los documentales cinematográficos, presentan rápidamente una serie de imágenes urbanas. Según Rio, todos los hombres poseen un "cinematógrafo" en sus cabezas, movido por la imaginación, y las imágenes que se perciben pasan por el cerebro a un ritmo increíble. Rio define al que él llama "Homus cinematographicus" como un ser cuyo rasgo principal es la velocidad. El invento de los vehículos modernos - los trenes, los automóviles, los aviones- ha acelerado el ritmo de la existencia, y el cine, según Rio, no sólo refleja esta aceleración, sino que también contribuye con su propia velocidad (Süssekind 29-30).

Rio anticipó en sus crônicas y novelas lo que otros escritores iberoamericanos descubrieron en los años veinte. En México, Jaime Torres Bodet y Mariano Azuela experimentaban mucho con las técnicas cinematográficas durante esta década. Fue Torres Bodet el más prolífico de los novelistas entre los Contemporáneos. En tres de sus seis novelas se aprecian frecuentes experimentos de técnica cinematográfica. El entusiasmo de Torres Bodet por el cine mudo no se limitó a ser algo que él simplemente importara de España. Si bien su prolongada estancia en ese país, de 1928 a 1929, desempeñando el cargo de diplomático, ciertamente lo puso en más estrecho contacto con el medio bulliciosamente cinematográfico promovido por La Gaceta Literaria, el interés de Torres Bodet por el cine comienza tres años antes de su residencia en España, remontándose a 1925, cuando se dedicaba a elaborar reseñas de cine para la Revista de Revistas bajo el seudónimo de "Celuloide” en su columna regular "La Cinta de Plata” (Capistrán 13-14). De hecho, en 1926 escribió un ensayo en el que sugiere que la novela moderna, para poder sobrevivir, debe convertirse en algo análogo al cine moderno: "La novela...[h]a caído en desuso porque no era una forma literaria pura y porque, no siéndolo, no pudo competir con el cinematógrafo". El autor afirma que el cine constituye un buen modelo para el novelista actual, dado que es "más inteligente en recursos industriales, alimento sólido para esa

${ }^{14}$ Véase a J. Patrick Duffey, “Montage in Hispanic Vanguard Prose, 1926-1934: Neurasthenia, Back Projection, and Chase Scenes”, para un análisis del uso de esta técnica por varios novelistas españoles: Pedro Salinas en Víspera del gozo (1926), Azorín en Superrealismo (1929), Antonio Espina en Luna de copas (1929), Benjamín Jarnés en Teoría del Zumbel (1930), y Francisco Ayala en Cazador del alba (1930). 
hambre de imaginación sin esfuerzos que caracteriza a los hombres cuando integran un público” (Contemporáneos 10-11). Torres Bodet se aprovechaba de uno de estos "recursos industriales" del cine mudo, la velocidad, en varias escenas de sus novelas.

En Proserpina rescatada (1931), hay dos ejemplos ingeniosos de cómo Torres Bodet conecta la velocidad del cine mudo con la de los vehículos modernos. La novela trata la relación amorosa y mítica entre Proserpina Jiménez y Delfino Castro, y las desapariciones cíclicas de ésta, por padecer de una enfermedad incurable (esta Proserpina sólo puede ser "rescatada" por la muerte). La obra se divide en cuatro estaciones, dos en la Ciudad de México y dos en Nueva York. Proserpina es una mujer moderna, urbana, acelerada, cuyos "movimientos irradiaban ... una nerviosidad eléctrica” (190). Durante su estancia en Nueva York, Delfino y Proserpina viajan por la metrópoli en un coche, y las imágenes urbanas pasan "por las ventanillas, a ambos lados del coche, con una prisa sorda, como en la doble pantalla de un cinematógrafo mudo” (200). En la novela de Torres Bodet, la velocidad de Nueva York sólo se puede expresar en términos del cine mudo. Como Sergei Eisenstein en El acorazado Potemkin (1925), como Fritz Lang en Metropolis (1927), Torres Bodet crea en 1931 una versión literaria de lo que Eisenstein designaba como “montaje ideológico", o sea, aquél en el cual las imágenes se yuxtaponen rápidamente a fin de establecer una relación conceptual (Cook 176). Las ventanillas del "Packard” del amigo de Proserpina y Delfino se convierten en dos pantallas, en las cuales se proyecta velozmente un caos de imágenes (la proa de Staten-Island, el puente de Brooklyn, cuatrocientos ochenta rebaños de locomotoras, etc.). El choque de imágenes urbanas de las dos pantallas automovilísticas expresa la abundancia de estímulos visuales ofrecidos por la gran urbe moderna. Como los espectadores del cine de atracciones descritos por Gunning, Delfino y Proserpina sienten el placer de la estimulación visual del choque caótico de tantas imágenes.

Posteriormente, Delfino se marcha de Nueva York, y regresa a México en tren. Torres Bodet relaciona la velocidad de las imágenes que el protagonista ve por la ventanilla con la velocidad de las películas de vaqueros del cine mudo, películas como las que hizo el rey de los vaqueros cinematográficos de los años veinte, Tom Mix. Uno de los aspectos más atractivos de las películas del oeste de los años veinte - especialmente las de Mix - era la velocidad vertiginosa y cómica de las numerosas escenas arriesgadas. Durante su viaje de regreso a México, Delfino va mirando a través de la ventanilla del tren y parece que lo que está observando es una cinta de vaqueros escenificada en los pequeños poblados de Texas:

¡Velocidad! Paisaje nocturno, idéntico siempre a sí mismo. Página sostenida, en ciertos renglones confusos, por los asteriscos de los postes telegráficos. Nada....De vez en cuando, en las estaciones próximas a la frontera, no se detenía ya el tren. Sólo el timbre automático del guardavías anunciaba entonces, del otro lado de los vidrios, el sueño de la ciudad. Allí, en cierto rincón de la noche, dormían probablemente, como en guardarropa de Hollywood, caballos, paisajes, pistolas, idilios y sombreros de cowboys... Vencido por esta ilusión cinematográfica, el silbido de la locomotora, al enrollarse, formaba un nudo corredizo. Lazo vaquero. Rápidamente, se estrangulaba a sí mismo. (236) 
La velocidad aquí es explícitamente cinematográfica. Las imágenes de la película vaquera que pasan por la ventanilla — “caballos, paisajes, pistolas, idilios y sombreros de cow-boys”- desfilan a un ritmo acelerado, el ritmo cómico de las películas de los vaqueros del cine mudo de los años veinte. Delfino intenta perderse en una "ilusión cinematográfica”, pero el lazo vaquero lo despierta al final y pone fin a esta distracción agradable del "guardarropa de Hollywood”. Torres Bodet expresa muy bien en este pasaje tanto la velocidad cinematográfica como el humor de una escena de una película del far west.

Hay otros ejemplos en la literatura iberoamericana de esta conexión explícita entre la velocidad del cine mudo y la de los vehículos modernos. En El desquite (1925), una de sus tres novelas vanguardistas, Mariano Azuela utiliza un tren rápido como un vehículo temporal que conduce y trae de vuelta del pasado al narrador. Asimismo, Azuela emplea las ventanillas del tren como pantallas de cine mudo. Las imágenes pasan fugazmente ante los cristales: "La enorme plancha de asfalto flanqueado de bosque, silbatos, arbotantes, ruedas, peatones, edificios...” (1:978). Más adelante, el narrador empieza a ver imágenes del pasado en forma de una figura a la cual él designa "madrecita”, mientras el paisaje campestre que pasa ante la ventanilla del tren representa el presente: "Madrecita, paisaje, rumores, aromas y madrecita, paisaje, aromas, rumores y puro paisaje y nada...” (2:1001). Azuela establece relaciones entre el pasado y el presente, las cuales se tornan sumamente complicadas en El desquite. El autor enfatiza la naturaleza cinematográfica de estas relaciones cuando, por ejemplo, cierra el pasaje anterior comparando el repentino oscurecimiento del cielo con las técnicas de iluminación propias del cine: "se enfosca con rapidez de film” (2:1002)..$^{15}$

Xavier Abril y Oswaldo de Andrade también conectaron la velocidad del cine y la de los medios de transporte. Abril describe su viaje en tren de Hendaye a París en un capítulo titulado "Film" de su obra narrativa Hollywood (1931). El narrador declara que es imposible leer un libro en el tren, porque leer no es una actividad suficientemente veloz. Los libros no poseen la rapidez del "film" del paisaje que se ve por la ventanilla. Sólo la poesía de Blaise Cendrars (1887-1961), una poesía notable por su velocidad cinematográfica, ${ }^{16}$ es apropiada para un viaje en tren:

El paisaje no permite, dentro de su régimen natural $-\mathrm{y}$ de naturaleza—, la lectura de libros, de esa manera salida de los trenes: un poco al libro y otro poco al paisaje. Este tiene una sutil malicia. A veces nos cubre con un árbol. Sólo el paisaje es apto a la velocidad de un ferrocarril o al ruido de un poema de Cendrars. Esto, porque quiere lo que le llega a ritmo (177).

Abril sugiere que el paisaje visto por la ventanilla crea una película de rápidas imágenes que manifiestan un ritmo más acelerado que el de la literatura en general.

\footnotetext{
${ }^{15}$ En su estudio de 1981, Eliud Martínez comenta este pasaje, pero no alude a su carácter cinematográfico (61).

${ }^{16}$ Véase Dix-Neuf Poèmes élastiques. El cineasta Jean Epstein comenta la influencia de la velocidad del cine en los poemas de Cendrars en su libro La Poésie d'aujourd'hui, un nouvel Etat d'Intelligence (1921). Guillermo de Torre glosa las ideas de Epstein en su Literaturas europeas de vanguardia (1925), 288-89.
} 
Algunos críticos ya han comentado la influencia del cine en varias obras de la vanguardia brasileña, especialmente en ciertos textos de Oswald de Andrade. ${ }^{17}$ En el fragmento 110 de Memórias Sentimentais de João Miramar (1924), Oswald expresa la visión de la naturaleza que posee el protagonista en términos cinematográficos. Este fragmento tiene el título "Fita em séries", indicando la serie de imágenes del montaje que sigue. El protagonista y su novia observan el paisaje desde la ventanilla de su coche alquilado. Las imágenes de la escena parecen allanarse en la pantalla, hasta que los propios observadores forman parte de esta pantalla bidimensional: "E diante do grande mar emergido dum rochedo e da ilha desgrenhada dos urubus, éramos a paisagem na paisagem” (65). Los espectadores se han convertido en un elemento de fondo de la escena. Oswald conecta la velocidad de las imágenes con la del cine cuando describe la perspectiva del coche alquilado, una perspectiva que abarca un panorama "do centro acachapado às areias inspiradoras de cenas fílmicas” (65). Uno de los poemas de Pau Brasil (1925), "Documental”, es, tal vez, el mejor ejemplo de cómo este autor relaciona las dos velocidades. Describe “no sentido cinematográfico” la vista desde la ventanilla del tren: "Floresta colinas cortes/E súbito a fazenda nos coqueiros/Um grupo de meninas entra no filme” (112). Primero se ven las colinas, después la hacienda, y al final el grupo de niñas aparece, "entra no filme". La ventanilla se convierte en una pantalla en la cual se forma un montaje de imágenes.

A veces los autores de este período hacen comparaciones explícitas entre el cine y los vehículos modernos que se refieren a la técnica de la proyección de fondo, la cual consiste en proyectar una escena en una pantalla situada a espaldas de los actores (a menudo sobre una ventana), de modo que parece que éstos van viajando en un vehículo mientras el paisaje rural o urbano va pasando. ${ }^{18}$ En Margarita de niebla (1927), por ejemplo, Torres Bodet compara el paisaje que vuela por la ventanilla de un coche con los rollos de cartón con los que los primeros cineastas utilizaban para simular la imagen de un coche en movimiento: “a cada lado del automóvil, un paisaje que parece escenario de cartón enrollado con que el cinematógrafo, al girar, simula el movimiento de los viajes...” (67). Un año más tarde, en su novela corta El joven, Salvador Novo conecta las dos velocidades de esta manera:

Estos automóviles...se conocieron mucho en el cine; en vistas panorámicas iluminadas, marca Pathé, de pronto daba vuelta un Renault. También en las vistas italianas. A la Hesperia_-decana de los argumentos—pannes frecuentes le daban ocasión de desesperar desde la portezuela que no podía abrir. (540)

\footnotetext{
${ }^{17}$ Antônio Cândido, comentando la novela Os Condenados (1921), concluye que Oswald fue "o lançador da técnica cinematográfica em nosso romance” (citado en Campos xl). Haroldo de Campos está de acuerdo con Cândido cuando dice que "[e]sta técnica é uma constante na obra de Oswald" (xl). Campos y K. David Jackson afirman que Oswald a menudo emplea el montaje. Jackson nota, por ejemplo, que los 163 fragmentos de Memórias Sentimentais de João Miramar se organizan por “[uma] lógica da montagem” (20). Süssekind sostiene que la literatura cinematográfica empieza en Brasil con Memórias Sentimentais y Serafim Ponte Grande (1933), de Oswaldo, Macunaíma (1928) de Mário de Andrade, y Pathé Baby (1926) de António de Alcântara Machado (29).

${ }^{18}$ Esta técnica se desarrolló durante los primeros años de la historia del cine: Edwin S. Porter, en su The Great Train Robbery (1903), probablemente haya sido el primero en emplearla (Cook 666).
} 
El paisaje que se aprecia desde la perspectiva de tan rápidos automóviles viene producido por una proyección de fondo por medio de una cámara, marca Pathé, la cual proporciona tomas panorámicas tan fascinantes que el espectador de la película se ve tentado a abrir la portezuela a fin de lograr una mirada más minuciosa.

Para concluir esta sección, hay que examinar otra clase de relación entre la velocidad del cine mudo y la de los vehículos, cuando los autores no hacen una comparación explícita sino que sólo sugieren la velocidad cinematográfica. De este modo, un escritor aparentemente no vanguardista como, por ejemplo, Martín Luis Guzmán, puede aprovechar las técnicas innovadoras de la vanguardia. Buen ejemplo de esto es su novela, La sombra del Caudillo (1929), la que ciertamente constituye, junto a Los de abajo de Mariano Azuela, una de los mejores obras generadas a raíz de la Revolución Mexicana. Esto es cierto no sólo porque la novela retrata con gran exactitud la ciega ambición que caracteriza a un ministro de guerra, así como el amplio y corrupto dominio ejercido por un Caudillo sobre la sociedad mexicana durante el período revolucionario. También se debe al extraordinario dominio que Guzmán tiene de la técnica literaria a lo largo de la novela. Por ejemplo, el autor a veces imita la velocidad del cine mudo en varios pasajes con el fin de transmitir una visión de la violencia, el caos, la confusión y la excitación que prevalecían en la sociedad mexicana a inicios de los años veinte. A menudo Guzmán describe la afluencia de imágenes que los personajes contemplan desde las ventanillas de sus automóviles, sobre todo desde el Cadillac de Aguirre, llamativo símbolo de la arrogancia y el poder que éste ostenta. Guzmán simula en estas escenas, sin mencionarlo explícitamente, la técnica cinematográfica de la proyección de fondo. El autor tuvo la oportunidad de presenciar muchos de los primeros ejemplos de proyección de fondo, ya que él era un ávido cinéfilo, sobre todo en la época en que estuvo exiliado en España y Nueva York, de 1915 a 1920. Durante el tiempo en que estuvo en España, Guzmán escribió, junto con su compañero de exilio Alfonso Reyes, varias reseñas fílmicas para la revista semanal España. Ambos autores firmaban sus reseñas con el seudónimo de Fósforo.

Al inicio de la obra, el Cadillac de Aguirre se detiene y el conductor procede a abrirle a éste la puerta. Mientras Aguirre y su amigo Axkaná conversan, se ve cómo una serie de agradables imágenes del paisaje urbano se mueven en la "pantalla” constituída por la ventanilla del automóvil, en el momento en que la portezuela se abre:

Se movieron con el cristal, en reflejos pavonados, trozos del luminoso paisaje urbano de aquellas primeras horas de la tarde — perfiles de casas, árboles de la avenida, azul de cielo cubierto a trechos por cúmulos blancos y grandes... (733)

Guzmán se vale del cristal de la ventanilla para combinar las imágenes del contorno de las casas, los árboles a lo largo de la avenida y el cielo azul. Más tarde, Guzmán utiliza montajes de proyección de fondo para resaltar tanto la ciega ambición de Aguirre como su posterior arrepentimiento respecto a esa ceguera en el momento en que va en su automóvil justo antes de su asesinato. En su ascenso por la escalera política, Aguirre no tiene el tiempo o la disposición para contemplar las imágenes que pasan por la ventanilla de su veloz Cadillac. Es el narrador quien describe para el lector las imágenes que pasan inadvertidas para Aguirre: 
El auto corría hacia la ciudad con todo el vigor zumbante de sus cuarenta caballos. Aguirre iba absorto. Su retina, ociosa, percibía apenas las rayas, como de exhalación, que los ornamentos del paseo parecían trazar en los cristales. Pasaron, sin que él los viera, los leones de la entrada del bosque; pasaron luego los hitos de la columna; pasó el jardincillo de las palmas. Y de ese modo su vago mirar fundió en unos cuantos segundos el paisaje de la fuente sevillana, próxima a las masas de los árboles, y el de la glorieta de Cuauhtémoc. (776)

En este momento, Aguirre está tan absorto en sí mismo que es incapaz de percibir el vívido montaje que fluye por la ventanilla. Sin embargo, hacia el final de la novela, cuando se le conduce por la fuerza en otro auto, hacia su muerte, finalmente logra encontrar tiempo para observar la "película” de la ventanilla:

[Aguirre] se entretuvo en observar, inmóvil la pupila, el desplazamiento paralelo de las dos blancas columnillas de polvo que los camiones iban haciendo adelante. Soplaba una brisa suave; los dos trazos, oblicuos respecto de la carretera, se elevaban en forma singular: mientras, arriba, la mitad de ellos se esparcía sobre el profundo azul del cielo, las mitades de abajo, finas, esbeltas, hacían dos cortes enérgicos en la verde masa de las montañas. Nunca hasta esa hora había descubierto Aguirre que tal interés pudiera encerrarse en la armonía de las formas y los colores. Lamentó por un momento, sin pretenderlo, la ligera miopía de uno de sus ojos. (930)

Del polvo que levantan las llantas de los camiones se forman unas columnas, las cuales fragmentan la visión que posee de las montañas a la distancia, creándose con ello un efecto caleidoscópico que le parece fascinante.

\section{LA VELOCIDAD CINEMATOGRÁFICA Y LOS DEPORTES MODERNOS}

Una indicación de la influencia poderosa de la velocidad del cine mudo y la de otros aspectos de la sociedad latinoamericana durante los años veinte se encuentra en un ensayo de Jorge Romero Brest (1905-1989), uno de los críticos de arte argentinos más importantes del siglo xx. ${ }^{19}$ Romero Brest era un hombre con diversos intereses. Crítico de arte y docente argentino, polémico y de gran influencia en las artes plásticas de la Argentina, también era de los primeros expertos en educación física, un miembro fundador del CineClub de Buenos Aires, un aficionado al jazz, y un crítico literario que estaba al tanto de las ideas innovadoras de la Revista de Occidente y de sus ensayistas ilustres, Ortega y Gasset, Guillermo de Torre, y Antonio Espina, entre otros. En un número de 1929 de la revista cultural argentina Nosotros, Romero Brest escribió un ensayo con el título "El elemento ritmo en el cine y en el deporte”.

La idea del ensayo es que el autor percibe que hay un elemento común entre el cine y los deportes de equipo, es decir, los dos producen imágenes rápidas que se mueven y que se dividen en unas partes más pequeñas: una película crea las imágenes del movimiento

${ }^{19}$ Romero Brest era director del Museo Nacional de Bellas Artes y del Centro de Artes Visuales del célebre Instituto Di Tella. Publicó, entre otras obras, Más allá de la geometría: extensión del lenguaje artístico-visual en nuestros días y un estudio del arte de Prilidiano Pueyrredón. 
por medio de una concatenación de una serie de imágenes más pequeñas; y los deportes de equipo crean patrones visuales muy complejos de los movimientos rápidos de los jugadores individuales que trabajan juntos. Para Romero Brest, los jugadores individuales son como las imágenes individuales de una película que producen los patrones dinámicos que satisfacen el deseo moderno de la velocidad. Romero Brest utiliza las mismas palabras para describir la película El acorazado Potemkin de Sergei Eisenstein y un partido de fútbol o de baloncesto. La película de Eisenstein puede fotografiar objetos y hacerlos mover con una velocidad moderna, "a un ritmo implacable" (359). Asimismo, los deportes de equipo obligan a cada jugador a crear los patrones que obedecen a la velocidad moderna; de nuevo, Romero Brest utiliza la frase "a un ritmo implacable” (361). Su descripción de un partido de baloncesto también se puede aplicar a su manera de apreciar una película. "En el baskett (sic), que es tal vez donde el equilibrio de los ritmos es más perfecto, la emoción se produce por ambos caminos: admira la rapidez del movimiento, que en este juego adquiere espacialidad y además la sensación rítmica producida por los sujetos, combinando formas geométricas animadas de un dinamismo abrasador” (362). Romero Brest ve la misma rapidez del movimiento, la espacialidad, las formas geométricas y el dinamismo en el cine. Utiliza un lenguaje parecido al hablar sobre la danza moderna y el jazz. Su ensayo es un buen ejemplo de cómo los intelectuales latinoamericanos estaban formando estas conexiones, viendo la velocidad en fenómenos culturales muy diversos. Como Romero Brest, Vicente Huidobro también estableció la conexión entre las técnicas cinematográficas y la velocidad de los deportes de equipo, por ejemplo, en su novela humorística de 1929 sobre una versión modernizada del héroe de Castilla, Mío Cid Campeador.

\section{El Cid y la velocidad de Douglas Fairbanks, SR.}

Como otros autores vanguardistas, durante los años veinte Huidobro creó un género literario conscientemente híbrido que combinaba el cine y la novela, un género que llamaba "novela-film". ${ }^{20}$ Huidobro estaba tan interesado en las posibilidades del cine que hasta escribió y produjo una película cubista nunca distribuida en 1923. El guión para esta película se convirtió en su segunda novela-film, publicada en 1934 como Cagliostro: novela-film. Mientras estaba trabajando en ésta, publicó otra novela-film en 1929, Mío Cid Campeador. Huidobro decidió escribir esta obra cinematográfica después de conocer a Douglas Fairbanks, Sr., en Paris en 1927. Durante los años veinte, si Chaplin representaba la velocidad en las películas cómicas, Fairbanks la personificaba en las películas de acción como, por ejemplo, La máscara de Zorro (1920), Los tres mosqueteros (1921), y El ladrón de Baghdad (1924). Fairbanks le comunicó a Huidobro su deseo de participar en otra película de aventuras, ésta sobre el Cid, y sugirió que el poeta chileno

\footnotetext{
${ }^{20}$ Antonio Espina escribió dos novelas cinematógraficas, Pájaro pinto (1926) y Luna de copas (1929). El mexicano Jaime Torres Bodet produjo tres: Margarita de niebla (1927), Proserpina rescatada (1931), y Estrella de día (1933). Otro ejemplo de este tipo de hibridismo es Pathé-Baby (1926) del brasileño António de Alcântara Machado.
} 
le escribiera un guión. ${ }^{21}$ Ya que Fairbanks era de los actores más acrobáticos y veloces del cine mudo, no debe de sorprender que haya varios ejemplos de la velocidad cinematográfica en este homenaje a él, Mío Cid Campeador.

El Cid de Huidobro- una versión Hollywood de la vida de Rodrigo Díaz de Vivar — provee unas descripciones extremadamente visuales de las batallas tradicionales del Cid con los moros, y también revela una visión cómica de lo no tradicional del Cid— su adolescencia, su niñez, su nacimiento, y hasta el momento apasionado de su concepción en primer plano. La velocidad figura como un elemento fundamental en esta versión del Cid. Huidobro comenta su velocidad extraordinaria; su atletismo excepcional; y el hecho de que la fuente de su alta velocidad es el alto voltaje que corre por sus venas. Cabe mencionar aquí que Fernando Vela — como Huidobro en lo tocante al Cid_ compara la energía de Charlot al dinamismo de un tranvía eléctrico (237). A menudo es una velocidad eléctrica que suministra la energía del humor frenético de los años veinte. En cuanto al Cid, a la edad de quince años, Rodrigo "ya es un formidable atleta”, con "nervios sueltos como nervios de una máquina." Huidobro lo describe como "un anticipo muy superior a todos los sportsmen de hoy”. El Cid de Huidobro es "el inventor insuperado del muchacho yanqui, del futbolista y del cowboy”. Según Huidobro, "una violenta necesidad de movimiento agita todo su cuerpo" (808-09). El Cid posee una velocidad relámpago, ya que la electricidad está en su sangre. Es un superhéroe medieval de las tiras cómicas:

Mirad al Cid en las batallas .... Es el hombre eléctrico.... Por encima de la inspiración genial y de los cálculos rígidos, está la descarga a alta potencia, está la corriente de voltaje irresistible que un hombre puede hacer pasar de polo a polo de su ejército. (882)

Huidobro no duda en mezclar lo medieval con lo moderno. En su estudio reciente "Early Cinema and Modernity in Latin America”, Ana M. López vincula el cine mudo y la modernidad latinoamericana específicamente con este hibridismo temporal: "[A] crucial sign of Latin American modernity is a kind of temporal warp in which the premodern coexists and interacts with the modern" (49). ${ }^{22}$ Para describir los movimientos de alto voltaje del héroe medieval de un polo al otro en las batallas, Huidobro utiliza las técnicas cinematográficas, ya que sólo la cámara de cine posee la cantidad suficiente de ángulos y el campo visual de anchura suficiente para captar el movimiento perpetuo de este Cid modernizado.

A lo largo de toda la novela-film, Huidobro crea una perspectiva cinematográfica cuando convierte los ojos del lector o los de un personaje en lentes de cámara. Repetidas veces se dirige al lector, preguntándole, “¿Qué ves ahora?” Y nosotros los lectores le contestamos lo que vemos que está haciendo el Cid. Huidobro tiene más éxito con esta técnica casi al final de la novela-film cuando la esposa del Cid, Jimena, está observando a su marido mientras éste mata a miles de moros. Para captar toda la acción, Jimena sube

\footnotetext{
${ }^{21}$ De los pocos estudios sustanciales de las novelas cinematográficas de Huidobro es el de René de Costa, "Huidobro: From Film to Filmic Novel".

${ }^{22}$ El estudio fundamental del hibridismo cultural latinoamericano es el de Néstor García Canclini, Culturas híbridas: estrategias para entrar y salir de la modernidad (1989).
} 
a una torre y empieza a "rodar", a "filmar" la acción con sus ojos. Primero, ella tiene que ensanchar sus ojos como si fueran lentes de cámara: “Doña Jimena sigue atenta la batalla y todas las escenas se retratan en sus ojos agrandados para hacer entrar el enorme tumulto en su campo visual” (989). Después de presentar una toma panorámica del campo de batalla, Jimena empieza a enfocarse en unas tomas más cercanas de unos soldados específicos que luchan contra los moros con una velocidad eléctrica y moderna. Jimena describe la batalla desde cuatro ángulos distintos, y comenta la "rapidez” y el "delirante movimiento" de la espada del Cid. Huidobro resume el reportaje cinematográfico de Jimena de la batalla, llamándolo un espectáculo mortal "de un dinamismo nunca visto". Como Charlot en el cuento de González Rojo, como los jugadores del basket de Romero Brest, el Cid siempre emite “un dinamismo abrasador,” y este dinamismo sólo se puede representar con la velocidad del cine mudo.

UNA VELOCIDAD ARTIFICIAL, LA REPRODUCCIÓN TÉCNICA Y WALTER BENJAMIN

Como se ha visto, el ritmo acelerado del cine mudo tuvo un impacto significativo en la literatura iberoamericana de los años veinte y treinta. Los textos que se han examinado —los de México, Argentina, Chile, Perú y Brasil_- demuestran la influencia penetrante de la velocidad cinematográfica en este período. Pero las actitudes de los escritores hacia la velocidad revelan algo aún más notable: reflejan los cambios en el concepto del arte durante los primeros decenios del siglo xx. La variedad de encarnaciones literarias de la velocidad del cine no sólo ilustra algunas ideas del célebre ensayo de Walter Benjamin, “La obra de arte en la época de su reproductibilidad técnica” (1936), sino que a veces permite una ampliación de estas ideas.

En los textos ya analizados, la actitud parece inequívocamente positiva: los movimientos acrobáticos del Charlie Chaplin de Waldo Frank y González Rojo; el paisaje vertiginoso que pasa por los cristales de los vehículos de Marín, Torres Bodet, Novo, Azuela, Guzmán, Abril, y de Andrade; el dinamismo abrasador de los atletas y de los cineastas estudiados por Romero Brest; las hazañas heroicas y precipitadas del Cid de Huidobro. Había, sin embargo, una inquietud sobre la velocidad desenfrenada del cine. Por ejemplo, en Los tres berretines: (típica-football y cine): comedia asainetada de actualidad, en un acto y cuatro cuadros (1932) de los prolíficos dramaturgos argentinos Nicolás de las Llanderas y Arnaldo Malfatti, una familia porteña se enfrenta a las alegrías y a los problemas producidos por dos fenómenos modernos y veloces, el fútbol y el cine. En el primer "cuadro", el padre, Manuel, y su suegro, Severo, están solos en casa, quejándose, porque sus esposas e hijos han ido al "maldito cine”, de donde van a regresar “todos enloquecidos”. Manuel lamenta la desaparición de la comida dominical en casa con la familia unida. En el cine, la abuela, la madre y los hijos viven una vida más intensa de lo normal, en tierras más exóticas. La abuela está enamorada del actor Adolphe Menjou (o, como Severo lo pronuncia, “Adorfo Menjunje”). Según Manuel, “Toda la culpa tiene el cine”, pero no es sólo el cine. La velocidad del fútbol también amenaza la unidad familiar. Los hijos llegan después del partido "hechos papilla” y no sirven para nada. Al final de la obra, un año ha pasado, Manuel ya es un "hincha” de fútbol, ya que su hijo 
Lorenzo es un jugador estupendo, pero todavía le queda algo de su miedo a la velocidad del fútbol y del cine. Para Manuel, son fenómenos de excesiva intensidad.

EDUARDO [otro hijo de Manuel]—Hoy se vive intensamente.

MANUEL-Ahí está el mal. Que todo se quiere disfrutar en un momento, que nos jugamos enteros y si fracasamos, quedamos deshechos para toda la vida. Que no mezclamos las diversiones con el trabajo, el descanso con la actividad.

LORENZO—Y...estamos en el siglo de la rapidez, viejo.

Por un lado, Manuel se ha convertido en un hombre moderno pero, por otro, teme que se esté perdiendo algo con la velocidad que traen el cine y los deportes nuevos.

Los mismos autores que elogian e imitan ciertos aspectos del cine mudo también a veces critican la falsedad y la superficialidad del cine, el aspecto mecánico de la velocidad, y la adoración de las máquinas y de todo lo artificial. Por ejemplo, en Estrella de día (1933), Torres Bodet describe la relación entre Enrique, un joven cinéfilo, y Piedad Santelmo, una estrella de cine. Curiosamente, la obsesión de Enrique con Piedad no lo empuja cada vez más hacia el mundo de la fantasía. Al contrario, al concentrarse mucho, va atrayendo cada vez más a Piedad hacia la realidad. Llega un momento en que a Enrique no le satisface la artificialidad de la imagen cinematográfica de Piedad. Quiere conocer a la mujer verdadera, verla toser y estornudar, como una persona normal. Al final de la novela, Enrique logra conocer a Piedad, y a ella también le complace el que Enrique la haya apartado del mundo falso y fantástico del cine mudo. Esta novela también rechaza la velocidad cinematográfica, como parte de un mundo falso y artificial. Aunque Waldo Frank admira la energía optimista de la velocidad de Chaplin, censura la idolatría materialista de la velocidad de las máquinas. En su análisis de la cultura norteamericana Our America (1919), estima mucho más los valores humanos que las capacidades de las máquinas. Chaplin mismo - la encarnación de la velocidad optimista en sus películas de los años veinte- critica la velocidad implacable de la cultura moderna en Tiempos modernos (1936).

La literatura de los años veinte y treinta revela una variedad de posturas hacia lo que Ortega y Gasset denominaba "la deshumanización”. Es una simplificación excesiva concluir que todo arte vanguardista es deshumanizado. El concepto de arte de esta época no es homogéneo, más bien es una mezcla de un entusiasmo por lo artificial y una preocupación por las consecuencias de éste. Los textos ya examinados, por ejemplo, revelan una admiración por la velocidad del cine mudo y, a veces, una ansiedad por su falta de humanidad. Benjamin reconoció el poder extraordinario del cine. Según él, cambió por completo el concepto de arte. Por primera vez - y esto es el efecto del cine- el hombre experimenta su ser entero y vivo, sin el aura. Es decir, el cine proporciona una réplica casi perfecta del ser entero y vivo, pero sólo es una reproducción artificial, no es un ser humano. El argumento del ensayo de Benjamin es bien conocido: la tecnología la litografía, la fotografía y, por último, el cine- es capaz de reproducir el objeto de arte, de un modo cada vez más perfecto, privándolo de su estado de ser único, de lo que Benjamin llama el "aura” del objeto. Los movimientos artísticos finiseculares y vanguardistas eran en parte reacciones a este asalto tecnológico contra el aura del objeto 
de arte. El cine le quitó el aura al objeto de arte con particular eficacia, porque era la reproducción de arte más perfecta hasta ese punto en la historia. Benjamin concluye que el cine reproduce eficazmente el objeto de arte y así destruye su aura, es decir, el estado de ser único del actor humano. En mi opinión, el cine no sólo reproduce la imagen original, sino que la mejora en ciertos aspectos. El cine puede acelerar la realidad. Le puede infundir una energía nueva, moderna, artificial. Como se ha visto, para muchos escritores lo artificial se convierte en algo atractivo, en la "genialidad del pronto" de Chaplin, por ejemplo. Al mismo tiempo, algunos autores caracterizan la velocidad artificial del cine mudo más bien como una posible amenaza.

Para concluir, la otra novela-film de Huidobro, Cagliostro, novela-film (1934), provee un entretenido ejemplo del impacto de la velocidad del cine mudo en la literatura iberoamericana de estos años. En la novela-film, Huidobro reproduce un cliché de los Westerns, una persecución a caballo que incluye un viejo truco: el momento en que el malvado se esconde detrás de los arbustos y deja que el comisario y sus hombres pasen y, después, el malvado sale en dirección opuesta. En este pasaje se combinan el humorismo, el cine y la velocidad:

\footnotetext{
En el mismo instante, los dos esbirros de Sartines en sus caballos, se lanzan tras él y desaparecen a la vuelta de la calle.

Otra calle. Albios [el malvado] se da cuenta de que lo siguen y apresura el galope de su caballo. Algunos minutos después, pasan dos policías por la misma calle.

Otra calle. Albios llega a toda carrera, mirando hacia atrás. Al pasar frente a una puerta cochera, entra y se esconde.

Los esbirros pasan velozmente ante la puerta y desaparecen a lo lejos.

Viéndolos alejarse, Albios parte como una flecha en dirección opuesta. (78)
}

Huidobro divide esta escena en cinco tomas cinematográficas: la imagen de los dos esbirros, la imagen de Albios acelerando, la imagen de Albios llegando a otra calle, la imagen de los esbirros mientras lo pasan y, finalmente, la imagen de éstos alejándose. Como en muchas películas de vaqueros de todos los tiempos, el malvado se escapa temporalmente - y parte con una velocidad cinematográfica, "como una flecha”.

Huidobro, en la introducción a la edición de la novela-film en inglés, escribe explícitamente que su obra híbrida utiliza el ritmo acelerado del cine: "Para el público de hoy, que ya tiene el hábito del cine....la acción no puede ser lenta. Los acontecimientos tienen que moverse a un ritmo mucho más acelerado. Si no, el lector se aburre” (Costa 17). Al llegar la modernidad, las sensaciones visuales de la vida cotidiana se multiplican y aceleran. La vida se convierte en un bombardeo constante y cada vez más rápido de estímulos sensoriales. Con la aceleración de los datos y la resultante fragmentación de la experiencia, los seres humanos intentan agarrarse a algunos momentos o fragmentos de la existencia. La velocidad del cine mudo permitía a los espectadores una manera de volver a conectar los fragmentos temporales. Les ofrecía unos instantes de lo que Epstein llamaba photogenie, el placer de ver los fragmentos de la vida diaria conectados de una manera significativa (Epstein dijo que jamás había experimentado la photogenie por más de un minuto (Charney, “In a Moment” 286)). La velocidad del cine mudo cambió la percepción visual de los públicos cinematográfico y literario. Huidobro sabía que sus lectores 
esperaban un ritmo más acelerado en Cagliostro: "la acción no puede ser lenta”. Como a los espectadores del cine de atracciones, a los lectores y a los escritores les apasionaba el asombro del movimiento veloz. Huidobro y otros escritores iberoamericanos de los años veinte y treinta crearon una literatura de atracciones, un mundo con personajes de la "raza más menuda" del cine mudo, un mundo donde las ventanillas de los coches y los trenes eran pantallas, los movimientos de los atletas se comparaban con los montajes de Eisentstein, y el Cid corría por el campo de batalla como Douglas Fairbanks, Sr.

\section{BiBLIOgrafíA}

Abril, Xavier. Hollywood (Relatos contemporáneos). Madrid: Ulises, 1931.

Andrade, Oswald de. Memórias Sentimentais de João Miramar . Obras Completas. II. Haroldo de Campos. ed. Río de Janeiro: Civilizacão, 1971. 13-94. Pau Brasil. Haroldo de Campos, ed. São Paulo: Globo, 1990.

Apollonio, Umbro, ed. Futurist Manifestoes. Nueva York: Viking, 1973. 127.

Arconada, César M. “Ensayo sobre Charlot”. Síntesis 4/40 Sep (1930): 21-29. 3 cómicos del cine. 1931. Madrid: M. Castellote, 1974.

Azuela, Mariano. Obras completas. 2 vols. México: Fondo de Cultura Económica, 1993. Benjamin, Walter. “La obra de arte en la época de su reproductibilidad técnica”. [1936]. Discursos interrumpidos 1. Buenos Aires: Taurus, 1989: 44.

Campos, Haroldo de. "Miramar na Mira”. Memórias Sentimentais de João Miramar. Obras Completas. II. Haroldo de Campos, ed. Río de Janeiro: Civilizacão, 1971.

Capistrán, Miguel. Prólogo. Crítica cinematográfica. Por Xavier Villaurrutia. México, DF: UNAM, 1970. 13-28.

Charney, Leo. "In a Moment: Film and the Philosophy of Modernity". Cinema and the Invention of Modern Life. Leo Charney y Vanessa R. Schwartz, eds. Berkeley: University of California Press, 1995. 279-94.

Charney, Leo, y Vanessa R. Schwartz, eds. Cinema and the Invention of Modern Life. Berkeley: University of California Press, 1995.

Cohen, Keith. Film and Fiction: The Dynamics of Exchange. New Haven: Yale University Press, 1979.

Cook, David A. A History of Narrative Film. Nueva York: W.W. Norton, 1981.

de Costa, René. "Huidobro: From Film to Filmic Novel”. Review: Latin American Literature and the Arts 29 May-Aug (1981): 13-20.

del Pino, José M. "El héroe est-ético de la vida moderna: Charlot y los vanguardistas españoles”. Cine-Lit II: Essays on Hispanic Film and Fiction. George CabelloCastellet, Jaime Marti-Olivella y Guy H. Wood, eds. Portland, OR, Corvallis, OR: Portland State University, Oregon State University, Reed College, 1995. 192-203. Montajes y fragmentos: una aproximación a la narrativa española de vanguardia. Atlanta: Rodopi, 1995.

Duffey, J. Patrick. De la pantalla al texto: La influencia del cine en la narrativa mexicana del siglo XX. México, DF: UNAM, 1996.

"Montage in Hispanic Vanguard Prose, 1926-1934: Neurasthenia, Back Projection, and Chase Scenes”. Hispanófila 118 (1996): 33-35. 
Epstein, Jean. "Le phénomène littéraire: Les conditions nouvelles du phénomène littéraire”. L'Esprit Nouveau: Revue Internationale Illustré de L'Activité Contemporaine 8, 9, 10 (1921-1922): 856-860; 965-969. Reimpresión: New York: Da Capo, 1968. Vol. 3. Trad. “The New Conditions of Literary Phenomena”. Broom 2 (April, 1922): 3-10. Reimpresión: New York: Kraus, 1967. Vol. 2. La poésie d'aujourd'hui, un nouvel état d'intelligence. Lettre de Blaise Cendrars. Paris: Éditions de la sirène,1921.

Espina, Antonio. “Desfile y ángulo-pinza”. El Sol Dec 1 (1927): 12.

Frank, Waldo. America Hispana. Nueva York: Scribner’s, 1931. Our America. Nueva York: Boni and Liveright, 1919. Primer mensaje a la América Hispana. Madrid: Revista de Occidente, 1930. “Retrato de Charles Chaplin”. Contemporáneos 2/3 (14 Jul 1929): 289-308. Salvos: An Informal Book about Books and Plays. Nueva York: Boni and Liveright, 1924. Virgin Spain: Scenes from the Spiritual Drama of a Great People. Nueva York: Boni and Liveright, 1926.

García Canclini, Néstor. Culturas híbridas: estrategias para entrar y salir de la modernidad. México, D.F.: Grijalbo, 1989.

González Rojo, Enrique. "El día más feliz de Charlot: Cuento cinematográfico en cuatro escenas y un apoteosis”. Contemporáneos 1/2 (5 Oct 1928): 113-30.

Gunning, Tom. "An Aesthetic of Astonishment: Early Film and the (In)Credulous Spectator”. Art and Text 34/1 (1989). Recopilado en Linda Williams, ed. Viewing Positions: Ways of Seeing Film. New Brunswick, NJ: Rutgers, 1994. 114-133.

"The Cinema of Attractions: Early Film, Its Spectator and the Avant-Garde". Wide Angle 8/3-4 (1986). Recopilado en Thomas Elsaesser y Adam Barker, eds. Early Cinema: Space Frame Narrative. Londres: BFI, 1990: 56-62.

" “Now You See It, Now You Don't': The Temporality of the Cinema of Attractions". Velvet Light Trap 32 (1993). Recopilado en Richard Abel, ed. Silent Film. New Brunswick, NJ: Rutgers, 1996: 71-84.

Guzmán, Martín Luis. Obras completas. Andrés Iduarte, ed. Vol. 1. México, DF: Compañía General de Ediciones, 1971. 2 vols.

Gyurko, Lanin A. "La muerte de Artemio Cruz and Citizen Kane: A Comparative Analysis”. Carlos Fuentes: A Critical View. Robert Brody y Charles Rossman, eds. Austin: University of Texas Press, 1982. 64-94.

Hall, Kenneth E. "Cabrera Infante and the Work of Alfred Hitchcock”. World Literature Today 61/4 (1987): 598-600.

Huidobro, Vicente. Cagliostro: novela-film. Santiago: Zig-Zag, 1934. Mío Cid Campeador, hazaña. Madrid: Compañía Iberoamericana de Publicaciones, 1929.

Obras completas. 2 Vols. Santiago: Zig-Zag,1964.

Jackson, Kenneth David. A Prosa Vanguardista na Literatura: Oswald de Andrade. São Paulo: Perspectiva, 1978. 
Llanderas, Nicolás de las y Arnaldo Malfatti. Los tres berretines (típica - football y cine); comedia asainetada de actualidad, en un acto y cuatro cuadros. Buenos Aires: La Escena, 1933.

López, Ana M. “Early Cinema and Modernity in Latin America”. Cinema Journal 40/1 (2000): 48-78.

Magny, Claude-Edmonde. The Age of the American Novel: The Film Aesthetic of Fiction Between the Wars. Eleanor Hochman, trad. Nueva York: Ungar, 1972.

Marín, Juan. “Klaxon”. [1926]. Looping. Santiago: Imprenta Nascimento, 1929. 59-63.

Marinetti, Filippo Tomasso. “La nuova religione-morale della velocità”. L'Italia futurista 1 (May 11, 1916): 1-3.

Martínez, Eliud. Mariano Azuela y la altura de los tiempos. Guadalajara: Gobierno de Jalisco, 1981.

Miller, Judy Held. “The Development of Cinematographic Techniques in Three Novels of Jaime Torres Bodet”. Tesis doctoral inédita. SUNY-Albany, 1975.

Morris, Cyril Brian. This Loving Darkness: The Cinema and Spanish Writer, 1920-1936. Oxford/Nueva York: Oxofrd University Press, 1980.

Murray, Edward. The Cinematic Imagination: Writers and the Motion Pictures. Nueva York: Ungar, 1972.

Novo, Salvador. El joven. [1928]. Toda la prosa. México, DF: Empresas, 1964.

Ortega y Gasset, José. “La deshumanización del arte”. 1925. La deshumanización del arte y otros ensayos de estética. Madrid: Alianza, 1986: 11-54. La rebelión de las masas. [1937]. Madrid: Alianza, 1986.

Pérez Firmat, Gustavo. Idle Fictions: The Hispanic Vanguard Novel, 1926-1934. Durham: Duke University Press, 1982.

Reyes, Alfonso, Martín Luis Guzmán y Federico de Onís. Frente a la pantalla. Manuel González Casanova, ed. México, DF: UNAM, 1963.

Richardson, Robert. Literature and Film. Bloomington: Indiana University Press, 1969.

Rio, João do. Cinematógrafo. Oporto: Chadron, 1909.

Romero Brest, Jorge A. "El elemento ritmo en el cine y en el deporte”. Nosotros 23/247 66 (Dec 1929): 352-67.

Sarlo, Beatriz. La imaginación técnica: Sueños modernos de la cultura argentina. Buenos Aires: Nueva Visión, 1992.

Una modernidad periférica: Buenos Aires 1920 y 1930. Buenos Aires: Nueva Visión, 1988.

Smith, Gary, ed. Benjamin: Philosophy, Aesthetics, History . Chicago: Universidad de Chicago, 1989.

Spiegel, Alan. Film and the Camara Eye: Visual Consciousness in Film and the Modern Novel. Charlottesville: University Press of Virginia, 1976.

Süssekind, Flora. Cinematógrafo de letras: Literatura, técnica e modernização no Brasil. São Paulo: Companhia das Letras, 1987. Trad. Cinematograph of Words: Literature, Technique, and Modernization in Brazil. Stanford: Stanford University Press, 1997.

Swain, James O. Juan Marín-Chilean: The Man and His Writings. Cleveland, TN: Pathway,1971. 
Torre, Guillermo de. Literaturas Europeas de Vanguardia. Madrid: Rafael Caro Raggio, 1925.

Torres Bodet, Jaime. Estrella de día. Madrid: Espasa-Calpe, 1933. Margarita de niebla. México, DF: Cultura, 1927.

Contemporáneos: Notas de crítica. Mexico City: Herrero, 1928.

Narrativa completa. 2 vols. México, DF: Colección Biblioteca, 1985.

Proserpina rescatada. Madrid: Espasa-Calpe, 1931.

Tyler, Joseph. “The Cinematic World of García Márquez”. Inti: Revista de Literatura Hispánica 16-17 (1982-1983): 163-71.

Vela, Fernando. “Charlot”. Revista de Occidente 20/59 (1928): 231-37. 